\title{
Die Herderlijken Brief van die Sinode van 1837
}

\author{
A D PONT
}

\section{Inleidende opmerkings}

Op 17 Oktober 1837 het ' $n$ buitengewone sinodale vergadering van die Nederduitsch-Hervormde Kerk van Zuid-Afrika in Kaapstad byeengekom. Hierdie vergadering wat deur 41 stemgeregtigde lede gevorm is, het ds A Murray van Graaff-Reinet as praeses en dr William Robertson van Swellendam as skriba verkies. As Kommissarisse Politiek het sir John Truter en mnr D F Berrangé as lede op die vergadering gesit. ${ }^{6}$ Hierdie vergadering wat na 1837 vervroeg is, het hom in hoofsaak met kerkregtelike en organisatoriese probleme besig gehou. ${ }^{2}$ Teen die einde van die vergadering, op 20 November 1837, het ds $\mathrm{T} J$ Herold ' $\mathrm{n}$ Herderlijken Brief wat hy in opdrag opgestel het, aan die vergadering voorgelê. Nadat ds $G W$ A van Lingen van Paarl en ds $\mathrm{H}$ A Moorrees gestel het dat hulle hulle nie met die Brief kan verenig nie "... werd dezelve door de groote meerderheid goedgekeurd en met dank aangenomen". ${ }^{3}$ In hierdie Herderlijken Brief het die sinode baie duidelik sy afkeuring van die Groot Trek, wat toe aan die gang was, uitgespreek. Die betrokke deel van die Brief lui soos volg: ${ }^{4}$

"Te regt bedroeft zich des Synode over den tegenwoordigen toestand van zoo vele Ledematen der Hervormde Kerk, die hunne haardsteden en altaren hebben verlaten, zonder een Mozes en Aaron de woestyn introkken, en zonder belofte of aanwyzing thans een Canaan voor zich opzoeken. De Synode houdt die allen verantwoordelyk voor hun gedrag, en wil hen slechts by deze gelegenheid herinnerd hebben aan hunne dure verplichting, die zy by den doop hunner kinderen op zich namen, en aan de belydenis, die zy zelve vrywillig aflegden, toen zy tot leden der kerk werden toegelaten. Zoo kan ook de Synode hare goedkeuring geenszinz hechten aan het voornemen van velen, die deze Nomaden op 't spoor wenschen te volgen, zoo lang zy zich niet overreden kan, dat het een gebiedende wenk der Goddelyke Voorzienigheid is, $-\mathrm{Zy}$ herinnert hen het zeggen van den Heiland, die zyn kruis niet opneemt en my navolgt, kan myn discipel niet zyn. Zy vermaant met allen ernst elk en eenen iegelyk, om onderworpen te zyn aan hen, die God over hen gesteld heeft als Zijne dienaars, en met alle aandrang te bidden, dat deze het wereldlyke zwaard met geregtigheid en beschei- 
denheid mogen dragen. Het os toch laakbaar, dat men de Overheid verge, dat deze zich uitsluitend naar onzen zin en belangen schikke, daar zy zelve bovendien in afhankelykheid van hoogere magten zich gedragen moet, en veeltyds naar ontwerpen handelt, welke betrekking hebben op het algemeene welzyn en die de toekomstige welvaart van het land verzekeren. De staatkunde moge dan ook in onze dagen verordeningen daarstellen, die met onze wyze van denken en handelen of met onze belangen strydig schynen, vergeten wy niet dat alle deze eene wyziging erlangen naar mate van onze gehechtheid aan godsvrucht en deugd. Blyft dan volstandig geloven en betrachten, wat de Godsdienst van Jezus in alle betrekkingen en toestand van hare belyders vordert. $\mathrm{Hy}$, de Alleenheerscher der wereld, gebruikt vorsten en natiën dan eens om volken en landen te zegenen, dan weder om ze te beproeven en te doen ontluiken, of ook wel om ze te tuchtigen en te straffen. Veel, wat ons heden kwaad toeschynt, wordt ons dikwyls op morgen tot eenen zegen; wat ons tydelyke schade veroorzaakt, een middel tot bevordering van ons eeuwig geluk.

Voorts, Broeders en Zusters! betoont $u$ in den burgerstaat als eerlyke, arbeidzame en nuttige leden der maatschappy, als getrouwe en gehoorzame onderdanen. Zoo zult gy gewis de bescherming en toegenegenheid wegdragen van hen die $u$ regeren. Zulks zal onder anderen eene gunstige aanbeveling voor $u$ zyn by Hare Majesteit, onze Geliefde Koningin, wiens troonsbeklimming gy moogt toe juichen, daar dezelve met een vast vertrouwen geschiedde op de Goddelyke ondersteuning, en wier verklaringen en eerste werksaamheden zoo zeer gekenmerkt zijn geworden met uitgedrukte gevoelens van hartelyke belangstelling in die bevordering van Godsdienst en deugd."

As mens hierdie paragrawe so lees, is dit wel belangrik om daarop te let dat op hierdie sinode van 41 lede 11 van die 22 stemgeregtigde predikante Skotte was en dat die Skotse predikante juis in die gemeentes gestaan het waarvandaan die Voortrekkers getrek het.

Met hierdie Herderlijken Brief het die sinode baie duidelik sy mening oor die Groot Trek uitgespreek en daardie mening ook kerkregtelik, binne die liggaam van die Kaapse Kerk, veranker.

Hierdie uitspraak oor die Groot Trek het wye nagevolge gehad en dit kan seker gesien word as 'n kerklike handeling wat die grootste enkele bydrae gelewer het tot die sogenaamde "kerklike verskeurdheid" van die Afrikaner. Daarby is hierdie Herderlijke Brief 'n mooi illustrasie van die feit dat die kerk maar al te maklik geneig is om die burgerlike owerheid na die mond te praat en daar in die gevlei te bly in plaas daarvan om die geregverdigde aspirasies en ideale van sy 
lidmate op staatkundig kulturele, godsdienstige en ekonomiese vlak ráák te sien, reg te evalueer en met die Woord van God te begelei en te lei.

\section{Opmerkings oor die Groot Trek}

Die Groot Trek was in die jare 1834/5 en later 'n groot beweging waar die getergde en onderdrukte Afrikanergrensboer uit die Kaapkolonie weggetrek het om 'n nuwe, eie vaderland in die leë binneland van Suidelike Afrika te soek. Uit die aard van die saak was hierdie volksverhuising nie 'n beweging wat uit enkelvoudige motiewe ontstaan het nie. Dit was 'n verhuising van groepe families wat met al hulle besittings die kolonie permanent verlaat het omdat die lewensklimaat vir hulle daar onleefbaar geword het. Dit was egter nie maar net 'n wilde awontuur nie maar veeleer 'n poging van Afrikaners om hulle selfbeskikkingsreg ten alle koste te handhaaf. Hulle was bereid om gevaarlik te lewe ter wille van hulle ideale en het nié kans gesien om in ' $n$ leefklimaat te bly waar daar vir die uitbou van die Afrikanerideaal geen moontlikheid meer was nie. ${ }^{5}$

Uit die aard van die saak het stoflike sowel as nie-stoflike redes 'n rol gespeel om die grensboere te beweeg om te trek. Die vooruitsig van 'n nuwe vaderland waar in rus en vrede geleef en gewerk kan word en waar' $n$ ekonomies-bevredigende bestaan gevoer kon word, was baie aanloklik. ${ }^{6}$ Belangriker was egter die feit dat in die Engelse kolonie, vanweë die koloniale beleid, die grensboer oortuig geraak het dat daar vir hom nie meer ' $n$ toekoms bestaan het nie. Die geleidelike integrasieproses waar die Hottentot, die vrygemaakte slawe en die swartes ingetrek is in die blanke gemeenskap en medeseggenskap oor die Afrikaner gegee is, het die grensboer-Afrikaner oortuig dat daar vir hom in 'n so 'n situasie nie meer 'n leefruimte sal oorbly nie. ${ }^{7}$ Daarby het gekom die verengelsing van kerk, skool en gemeenskap en die veragting van die Afrikaner se geestesgoedere. ${ }^{8}$ Hoewel die Afrikaner-grensboer nog nie 'n sterk ontwikkelde nasionale besef gehad het nie het hy instinktief aangevoel dat sy eiesoortigheid, sy nasieskap en sy selfbeskikkingsreg nie meer in die koloniale situasie uitgeleef kan word nie. ${ }^{9}$ Die Voortrekker-Volksraad in Natal het in 1839 die saak soos volg gestel: ${ }^{10}$

"Uit oorzaak van dagelijksche verwaarlozing en verachting van hunne Regten en Voorrechten - ondergane beleedigingen, vernederingen en bespotting in eer en reputatie, verkrachting van recht en eigendom en leven genoodzaakt zyn geworden hun dierbaar Vaderland en vele hartelyke geliefde betrekkingen, achter te laten."

Die Groot Trek wat die ideaal gestel het om 'n onafhanklike 
Afrikanerrepubliek in die leë binneland te vestig, was 'n groot stap in die nasionale bewuswording van die Afrikaner en ook ' $n$ duidelike verwerping van die Engelse koloniale heerskappy en die Engelse imperiale strewe. Die Voortrekkers het, deur weg te trek uit die kolonie, op vreedsame maar baie duidelike wyse hulle van imperiale Engeland en alles wat dit beteken het, losgemaak. ${ }^{11}$

\section{Opmerkings oor die Kerk}

Die kerk in die Kaapkolonie het sy insig oor homself, sy geestelike inhoud en sy organisatoriese karakter grotendeels vanuit Nederland gekry. Die kerk was van die vroegste tyd af die godsdienstig-kerklike keersy van die wordende Afrikanernasie. Tot 1804 met die Kerckenordre van De Mist, wanneer die toleransiegedagte van die rasionalistiese Verligting ook hier in die kerklike lewe ingeplant word, was daar aan die Kaap een burgermaatskappy en een kerklike organisasie. Hoewel na 1804 en dan veral na 1806 wanneer daar 'n al groter toestroming van Engelse koloniste was, meerdere kerklike organisasies langs mekaar in die kolonie bestaan, het die Afrikaner nog grotendeels aan die kerk behoort wat homself in 1824 De NederduitschHervormde Kerk van Zuid-Afrika genoem het.

Die kerk wat ontstaan en gegroei het in 'n posisie van onderhorigheid aan die burgerlike owerheid, het 'n lang en moeisame stryd gevoer om hierdie al te noue bande met die owerheid los te maak. Dit het egter nie so maklik gegaan nie omdat die owerheid terdeë bewus was van die feit dat die kerklike organisasie ' $n$ baie belangrike stutorganisasie vir die burgerlike owerheid is en kan wees. Die noue saamgaan van owerheid en kerk het op die kerklike terrein en op die lewensterreine rondom die kerk aanvanklik weinig probleme opgelewer omdat die kerk en die owerheid in dieselfde nasionale gemeenskap gewortel was.

$\mathrm{Na} 1806$ word die owerheid egter 'n vreemde, Engelse owerheid en behoort die owerheidspersone eerder aan die Anglikaanse, Engelse staatskerk as aan die Afrikanerkerk in die kolonie.

Hoewel die kerk in 1824 'n eie kerkwet kry sodat die gemeentes nou in een geordende geheel saamgesnoer word en daar nou ook vir die eerste maal rings- en sinodale vergaderings van die ampte gehou kan word, het dit nog nie beteken dat die seggenskap en gesag van die owerheid in die kerk verminder het nie.

Kleynhans stel hieroor: ${ }^{12}$

"... die sinode in teorie die hoogste gesag in kerksake was, terwyl die goewerneur in die praktyk was, aangesien hy, na luid van die reglement, die reg gehad het om die besluite van die Sinode nietig te verklaar as hy hom daarmee nie kon vereenselwig nie." 
Daarby was die predikante nie alleen staatsbesoldigde amptenare nie maar ook afhanklik van die goewerneur vir hulle plasing en verplasing. Tereg stel Kleynhans dan ${ }^{13}$ dat "die goewerneur eintlik in die praktyk die hoof van die kerk was."

Vanuit hierdie situasie word dit dan begryplik dat dit vir die opvolgende Engelse goewerneurs nie moeilik was om die politiek van verengelsing van die Afrikaner in die kolonie deur middel van die Afrikaanse kerk daadkragtig te bevorder nie. ${ }^{14}$ Gelaai met Skotse predikante het die kerk dan ook manmoedig saamgewerk "... to promote the extension of the English language also as far as practicable." 15

Samevattend kan die stelling van Spoelstra aanvaar word wanneer hy sê: ${ }^{16}$

"Die predikante van die grensdistrikte was vanweë die politiek van verengelsing uitsluitend Skotte gewees, wat die wese van die Groot Trek en die siel van die Afrikaner nie kon begryp nie. Daarby was hulle gesalarieerde amptenare van die owerheid waarteen die Trek in reaksie was. Die Voortrekkers is gevolglik van die predikante vervreem en het hulle van belangeloosheid en politieke partydigheid verdink."

Wanneer die Groot Trek op gang kom en dit duidelik word dat die Trek die oosgrens van die kolonie grotendeels van sy standvastige en betroubare bewoners stroop, neem die burgerlike en kerklike owerhede vir die eerste keer behoorlik kennis van die Afrikaner se reaksie teen die lewensomstandighede wat op hom afgedwing was. Die Groot Trek het die burgerlike owerhede in 'n baie ernstige verleentheid gebring ${ }^{17}$ maar die owerheid het nie die vermoë gehad om die Trek daadwerklik te stuit nie. Daarom is getrag om deur middel van oorreding en flikflooiery die grensboere oor te haal om tog maar in die kolonie te bly. In hierdie propaganda-veldtog téén die Groot Trek is die Kaapse Kerk nou ook ingespan. Dit is teen hierdie agtergrond wat die Herderlijken Brief van 1837 gelees moet word.

Dat dit nie so moeilik was om die kerk hier te betrek nie, word bewys deur die houding van sy predikante. In 1838 het die invloedryke scriba synodi, dr William Robertson van Swellendam net soos $\mathrm{dr}$ A Faure positief gereageer op die beroep van die Goewerneur in The Government Gazette van 4 Mei 1838 dat die predikante tog hulle invloed moet gebruik om die Trek teen te gaan. ${ }^{18}$ Spoelstra is reg as hy stel: ${ }^{19}$

"Die predikante van die staatskerk het natuurlik eerder die staat by die lidmate as die lidmate by die staat verteenwoordig. Daarom kon die Goewerneur reken op die steun van die kerkorganisasie om die Trek te bekamp." 


\section{Die Gesag van die Herderlijken Brief}

Die vraag wat nou na vore kom, is watter gesag die Herderlijken Brief in die kerk gehad het. Allereers kan dan gestel word dat 'n herderlike skrywe van ' $n$ sinode nie maar net 'n toevallige mening van 'n kerklike vergadering is of kan wees nie. In hierdie geval was dit 'n amptelike skrywe wat in opdrag van die vergadering deur 'n lid van die vergadering, ds T J Herold, ${ }^{20}$ opgestel is, deur die vergadering beoordeel en daarna, na ' $n$ behoorlike stemming, aanvaar is. ${ }^{21}$ Dit beteken dat hierdie Herderlijken Brief op dieselfde vlak te staan kom as enige ander sinodale besluit, beslissing of uitspraak. Assodanig is dit die wel oorwoë mening of beslissing van 'n vergadering van die ampte wat deur die Kerkwet van 1824 soos volg omskryf word:

"Art 9 Die hoogste directie der Hervormde Kerk in deze volksplanting omtrent Kerkelyke zaken berust by de Algemeene Kerk Vergadering.

Art 10 De Algemeene Kerk Vergadering is belast met de zorg voor de algemeene belangen der Hervormde Kerk in deze Volksplanting, en met opzigt tot dezene, in het byzonder, met de zorg voor alles wat de openbare Godsdienst en de Kerkelyke instellingen betreft."

Dit beteken dat die 1837 sinode 'n algemeen-bindende uitspraak, wat van alle lidmate, ampsdraers en vergaderings van die ampte gehoorsaamheid en navolging eis, kan maak en ook met hierdie Herderlijken Brief gemaak het. ${ }^{22}$ As hoogste kerklike vergadering ${ }^{23}$ het die sinode die pretensie om op grond van die Woord gelei deur die Gees 'n uitspraak te maak wat staan en wat vanweë hierdie pretensie ook gehoorsaamheid opeis. So 'n beslissing kan alleen deur 'n opvolgende sinode verander of verwerp word. Inmiddels was die mindere kerklike vergadering en die lidmate gebind om hierdie uitspraak te aanvaar en te gehoorsaam.

Daarby kom dat hierdie Herderlijken Brief óók deur die Kommissarisse Politiek, die verteenwoordigers van die burgerlike owerheid, aanvaar en goedgekeur is. In dié sin het die Herderlijken Brief as 'n geapprobeerde uitspraak van die staatskerk seker minstens dieselfde gesag as 'n owerheidsproklamasie gehad en kon ampsdraers en lidmate daarop reken dat die owerheid, vir so ver hy dit nodig geag het, die standpunt van die Herderlijken Brief sou ondersteun.

In dié lig gesien, is dit duidelik dat die Herderlijken Brief 'n belangrike en gesaghebbende uitspraak binne die kerklike verband was, 'n uitspraak wat van rigtinggewende en bepalende belang was. Daaruit kan afgelei word dat die Herderlijken Brief die finale standpunt van die Kaapse Kerk oor die Groot Trek reflekteer en dan nie net in 1837 nie maar óók vir die tyd daarna. 
As die verhouding van die Kaapse Kerk tot die Voortrekkerkerk gepeil en verstaan wil word, sal daar voortdurend teruggekeer moet word na die Herderlijken Brief van 1837 as die finale en gesaghebbende beoordeling van die sinode oor die Groot Trek. Dit sou ook onbillik teenoor die Kaapse Kerk en sy sinodale vergadering wees om hierdie Herderlijken Brief, wat met soveel erns en toewyding opgestel, bespreek en aanvaar is ánders te sien as 'n finale, duidelikomlynde, gesaghebbende beslissing wat voortdurend volledige gehoorsaamheid en navolging van almal binne die Kaapse Kerk geëis het.

\section{Opmerkings oor die inhoud van die Herderlijken Brief}

Die kerngedagte van die Herderlijken Brief is dat die Groot Trek, waardeur die grensboer-lidmate hulle aan die imperiale gesag van Engeland onttrek het, niks anders is nie as "opstand teen die wettige owerheid". ${ }^{24}$

Die motivering vir hierdie stelling is dan dat die grensboere nié deur 'n Moses of 'n Aäron gelei word nie en ook nie 'n belofte of 'n aanwysing het dat hulle inderdaad 'n nuwe vaderland in the "woestyn" sal vind nie. Die Groot Trek is nié "een gebiedend wenk der Goddelyke Voorzienigheid" nie.

Dit is waarskynlik met verwysing na hierdie stelling in die Herderlijken Brief dat die scriba synodi, dr William Robertson, in Julie 1838 in ' $n$ brief aan sy gemeentelede nie alleen wéér die Groot Trek afgekeur het nie maar ook gesê het dat die moord van Retief en sy sewentig en die moorde van die Voortrekkers in Natal 'n bewys is van "Gods afkeuring van het geheele plan". ${ }^{25}$

'n Mens kry die indruk dat omdat die Groot Trek nie polities-staatkundig aanvaarbaar is nie dáárom is dit ook nie kerklik-teologies aanvaarbaar nie.

Die tweede argument is dat almal wat tog nog wil trek, afgeraai word om dit te doen. Die grond waarop hierdie argument rus, is die verpligting wat die lidmate op hulle geneem het by die doop van hulle kinders en wat hulle uitgespreek het met die belofte wat hulle afgelê het toe hulle in die openbaar belydenis van geloof gedoen het.

Dit is maar 'n swak argument want dit is tog onhoudbaar om te dink dat ' $n$ mens se blote fisiese verplasing sal meebring dat hy sy kerklike beloftes nie nakom nie.

Die derde stelling is: "Het is toch laakbaar, dat men van de Overheid verge, dat deze zich uitsluitend naar onze zin en belangen schikke ..." Almal in die kerk moet maar geduldig wag totdat God die owerheid gebruik om die tydelike probleme reg te stel.

As hierdie argument teologies korrek sou wees, dan beteken dit 
dat die sinode óók ernstige bedenkings moes gehad het oor die regmatigheid van byvoorbeeld die optrede van die Hugenote in Frankryk gedurende die sestiende eeu. Dit dui op ' $n$ taamlik volledige gebrek aan historiese én teologiese insig en wys net hoe graag die sinode in die gevlei by die Engelse goewerneur wou bly.

Die slotargument is ' $n$ loflied op koningin Victoria wat in 1837 die troon bestyg het. Hierdie loflied, meer as baie ander dinge, toon hoe diep die verengelsingsproses al in die Kaapse Kerk ingevreet het.

Alles bymekaar geneem word hier by implikasie gestel dat die sinode die "opstandige gees" waaruit die Groot Trek, na die oordeel van die sinode voortkom, sensurabel ag. So word met'n stilswyende beroep op Romeine 13, waar die onderwerping aan die owerheid geëis word, die hele Groot Trek afgekeur.

In sekere sin was hierdie houding van die staatsamptenaar-predikante byna vanselfsprekend. Hulle was nie van plan om die owerheid, wat hulle gevoed het, teen te gaan nie. Daarby was dit ook duidelik dat daar by die sinode gladnie so 'n besondere besorgdheid oor die lidmate was as wat die Herderlijken Brief voorgee nie. Kitshoff stel: ${ }^{26}$

"Die apatie van die lede van die sinode was daarin geleë dat hulle die Groot Trek nie begryp het nie, en gevolglik nie daardeur vasgegryp is nie. Hulle het nie in hierdie mate as die Voortrekkers die "kwaad" in eie gees en die "tijdelijke schade" aan eie lyf ondervind nie, daarom kon hulle ook nie kom tot die visie van 'n "Canaan" anderkant die "woestyn" nie. Ook is dit waar dat die griewe van die grensboere nooit werklik grondig ondersoek is nie, sodat dit ook nooit in hul ware gedaante voor "die aandag van die kerk gekom het nie, maar meer in karikatuur."

In hierdie sin is die Herderlijken Brief 'n mooi voorbeeld van 'n plegtige sinodale uitspraak wat wel op 'n aanvaarde Skriftuurlike argument rus. Maar die Skriftuurlike argument is kwalik ter sake omdat die saak, waarop die Skriftuurlike argument van toepassing gemaak word, nie behoorlik nagevors en deurgrond is nie. Met die gevolg dat die twee dele van die argument nié by mekaar uitkom nie. Dit is natuurlik één van die tragiese momente in die kerklike lewe dat dit al so vele male in die geskiedenis van die kerk gebeur het dat die politieke voorkeure van die meerderheid van die lede van 'n kerklike vergadering tot ' $n$ sinodale uitspraak verhef is sonder dat daar ooit werklik na die waarheid of die houdbaarheid van die sinodale uitspraak gevra word. Só gebeur dit dan dat hierdie Herderlijken Brief éérder die kerk skade aangedoen en die lidmate gekwets het as dat dit die kerk en die geloof van die lidmate gebou het.

Die vasstelling dat die Groot Trek uit 'n opstandigge gees voort- 
kom, dat dit ' $n$ vorm van opstand teen die wettige owerheid is, was waarskynlik' $n$ argument wat polities volkome aanvaarbaar was. Om dan daarvandaan, op grond van Romeine 13 'n abolute onderwerping aan die owerheid te eis, moet egter as 'n teologiese kortsluiting beoordeel word.

Die groot vraag is of die Groot Trek wat 'n onttrekking was werklik as opstand gekwalifiseer kan word. Dié twee kan tog nie met mekaar gelykgeskakel word nie en is ook nog nooit met mekaar gelykgeskakel nie. Indien dit waar sou wees, dan was die kerkvader Joh Calvyn óók'n opstandeling omdat hy sy vaderland, Frankryk, verlaat het om die res van sy lewe as banneling in Genève te slyt. Was die Hugenote wat hulle na die herroeping van die Edik van Nantes onttrek het aan die jurisdiksie van die Franse koning, ondanks streng owerheidsmaatreëls dat hulle dit nie mag doen nie, opstandelinge wat hulle aan kerklike sensuur blootgestel het? Dit is vir my duidelik dat die Voortrekkers wat wegtrek uit die kolonie, hulle onttrek aan die jurisdiksie van die Engelse imperiale owerheid wel in verset is teén die owerheid en die owerheidsbeleid maar dat dit nog lank nie as opstand teen die owerheid in die sin van art 36 NGB, gekwalifiseer kan word nie. Eerder wil dit voorkom dat die sinode, in hulle ywer om die burgerlike owerheid ter wille te wees en 'n owerheidsbeleid kerklik te sanksioneer 'n denkfout begaan deur die vreedsame wegtrek, die selfopgelegde ballingskap, met opstand gelyk te stel.

Net so maak die sinode ' $n$ logiese denkfout deur te stel dat die Voortrekkers, omdat hulle hulle onttrek aan die Kaapkolonie en die min of meer geordende samelewing aan die oosgrens, nou hulle geloof sal verwaarloos en hulleself sal blootstel aan sedelike verwildering. Dit was natuurlik vir die Kaapse predikante 'n geliefkoosde argument dat onttrekking aan die Britse gesag ook'n "decay in morals and religion" sal meebring. Maar die werklikheid het meer as een maal aangetoon dat die Britse vlag nie vanselfsprekend daardie waarborg gedra het nie, soos die imperiale leër van Brittanje ook so treffend gedurende die oorlog van 1899-1902 gedemonstreer het.

Die sinode het met sy opmerking dat die grensboere wat trek opstandelinge is duidelik aangetoon dat hulle die situasie waaroor hulle 'n oordeel wil vel, nie ken nie. Die grensboere was nie opstandige anargiste wat daarna gedors het om die strukture ten alle koste te verander en met mag en geweld van alles weg te beweeg nie. Inteendeel, die Trekkers wou die teenoorgestelde bereik want hulle wou die aanvaarde en geërfde Afrikaner-geesteserfenis op godsdienstige, kulturele en staatkundige vlak bewaar en veilig stel. Die Engelse beleid in die kolonie het juis daardie geestes-eiendomlike van die Afrikaner bedreig en in gevaar gestel. Daarom, in plaas van verset en opstand, het die grensboere weggetrek uit die kolonie waar die Engelse owerheid nie daarin kon slaag om aan die inwoners 'n 
rustige en stil lewe in alle Godsvrug en deug te waarborg nie. Die sinode se uitgangspunt is egter dat die Engelse owerheid blaamloos is en daarom is hulle verplig om teen die feite in, die grensboere te beskuldig van 'n laakbare optrede.

Die feit dat die sinode van 1837 die Groot Trek as opstand teen die wettige owerheid omskryf, reflekteer méér op die kwaliteit van die sinode se teologiese insig en vermoë as wat dit as 'n enigsins aanvaarbare teologiese beoordeling van die Groot Trek beskou kan word. Met hierdie uitspraak kry ons ' $n$ vroeë voorbeeld in ons kerklike geskiedenis van die politieke teologie wat vandag so populêr is. Hier word 'n politieke standpunt teologies "regverdig" hoewel dit, by nader ondersoek blyk dat dié "regverdiging" teologies onhoudbaar is.

In 1837 het die Herderlijken Brief egter die steun van die meerderheid op die sinode gehad en omdat in die kerklike opset geoordeel is dat die meerderheid die waarheid besit, het hierdie Herderlijken Brief as die gesaghebbende, finale oordeel van die Kaapse sinode oor die Groot Trek bly staan. Dit is ook nooit herroep of verander nie. Al wat gebeur het, is dat met verloop van tyd, toe geblyk het dat hierdie Herderlijken Brief op ondeugdelike gronde berus, dit al meer in die vergeet-hoek gedruk is.

\section{Die Effek van die Herderlijken Brief}

Die eerste saak wat gestel kan word, is dat die Herderlijken Brief nie veel bygedra het om die Groot Trek te stuit nie. Selfs na die publikasie van die Brief het daar nog voortdurend van die grensboere die kolonie verlaat. Soos Muller dit stel: ${ }^{27}$

"Tydens die Groot Trek het die Oosgrensboere ook nie gehuiwer om hulle teen hul predikante te verset nie. Daar was ook lank reeds 'n tradisie van die selfstandige studie en vertolking van die Bybel, wat op afgeleë plase gereeld aandagtig gelees en sorgvuldig oordink is. Die grensboere se lekevertolking van Bybeltekste wat hulle aangegryp het, was geslagte lank reeds toegepas op hul besondere lewensomstandighede. Op die verhouding tussen Blank en Nie-Blank is by uitstek lig uit hul Statebybels gesoek. Waar ' $n$ parallel tussen die Afrikaners en die ou volk Israel sterk aangevoel is, is uit die Ou Testament letterlik toepassing op die grensboer gemaak. Bevele aan die ou Israeliete is soms ook as bevele aan Afrikanergrensboere beskou. Die grensboer-ouderling en -diaken, asook die gewone lidmaat, sou nie aarsel om op gesag van sy Bybel soms sy amptelike kerklike leier teen te gaan nie." 
Daar was dan ook in die grensboer-gemeenskap ' $n$ duidelike verwerping van die Herderlijken Brief naas die openlike verontagsaming daarvan ${ }^{28}$. Tog was daar wel lidmate wat aanvanklik beweeg is om nie te trek nie ${ }^{29}$ maar op die duur kon die Herderlijken Brief hulle óók nie oortuig dat dit kerklik-teologies onregmatig was om te trek nie. In die geheel gesien, kan gesê word dat die Herderlijken Brief nié in sy primêre doel geslaag het nie.

Waar die Herderlijken Brief wèl in sy doel geslaag het, was in die kring van die Kaapse predikante. Geen enkele predikant van die Kaapse Kerk was óf bereid om met die Trek saam te gaan nie óf om 'n werkkring onder die uitgeweke "opstandelinge" te aanvaar nie. S P Engelbrecht het afdoende aangetoon dat in die middel van die dertigerjare van die vorige eeu daar glad nie ' $n$ tekort aan predikante in die Kaapse Kerk was nie maar veel eerder 'n oorskot. ${ }^{30}$ Die argument dat daar geen predikante beskikbaar was nie, kan dus nie gehandhaaf word nie. Die Herderlijken Brief was vir die Kaapse predikante die onoorkomelike struikelblok wat tussen hulle en deelname aan die Groot Trek gestaan het. Die argument kan selfs verder gevoer word en gestel word dat die predikante van die Kaapse Kerk alleen dáár predikant wou wees waar die Britse vlag gewaai het. Die oorweging van aanstelling deur die Engelse goewerneur en die daarmee gepaardgaande sekerheid van lewenstog het hier seker die bepalende rol gespeel. ${ }^{31}$

Die standpunt van die sinode in sy Herderlijken Brief het nie net by die uitspreek van 'n veroordeling van die Groot Trek gebly nie. Die Ring- en Kerkraadsvergaderings van die oosgrensgemeenstes, wat uiteindelik die sinodale beslissing moes toepas, het die grensboere wat weggetrek het hulle kerklike voorregte in die Kaapse gemeentes ontsê. ${ }^{32}$ Die riglyn wat hier gevolg word, was seker nie alleen die Herderlijken Brief nie maar dit word ook deur ds T Reid van Colesberg in 1840 soos volg omskrywe: ${ }^{33}$

"Het Gouvernement heeft meer dan eens verklaard dat dezulken die over de grensen der Kolonie gaan, niet als Kolonisten moeten worden beschouwd, noch het voordeel of de bescherming deszelfs wetten hebben moeten."

Die Herderlijken Brief, soos die beslissing daarin vervat uitgelê en toegepas is deur die vergaderings van die ampte van die Kaapse Kerk, laat eintlik net één afleiding toe en dit is dat die predikante en vergaderings van die ampte van die Kaapse Kerk diegene wat uit die kolonie getrek het, gesien as mense wat nie net hulle Britse burgerskap nie maar ook hulle lidmaatskap van die Kaapse Kerk verbeur het. Dit is alleen in dié lig wat die "sydelingse sensuur" wat deur die Kaapse Kerk op die Voortrekkers toegepas is, verklaar kan word. 
Die Herderlijken Brief van 1837 het verreikende gevolge vir die verloop van die Afrikaner se kerkgeskiedenis gehad. In die eerste plek toon dit wel die byna onverbreekbare verbintenis wat die Kaapse staatsamptenaar-predikante met die imperiale Britse owerheid en sy beleid gehad het. Dit verklaar ook waarom die Voortrekkers in die Voortrekkerrepubliek sonder enige welslae probeer het om ' $n$ predikant uit die Kaapse Kerk te bekom. Die staatsamptenaar-predikante van die Kaapse Kerk kon en wou alleen die evangelie bedien daar waar die imperiale Britse vlag gewaai het. Met die toepassing van die "sydelingse sensuur" het die vergaderings van die ampte van die Kaapse Kerk verder duidelik gesê dat hulle die Voortrekkers nie meer as lidmate van die Kaapse Kerk beskou het nie. Hulle was "dwalende opstandelinge" wat nie die regering van haar Britse Majesteit Victoria lofprysend wou aanvaar nie. Dit het hulle, as lidmate, op daardie stadium vir die Kaapse Kerk onaanvaarbaar gemaak. So word die Herderlijken Brief 'n dokument wat 'n muur oprig tussen die Voortrekkers en die Kaapse Kerk.

In 1837 lê die Voortrekkers die fondamente van hulle eie staat en kerk. Dan word dit duidelik dat die Voortrekkerkerk, wat daar weliswaar nog in sy organisatoriese kinderskoene staan, onafhanklik van die Kaapse Kerk tot stand kom en ook 'n onafhanklike en nuwer kerklike organisasie op Suid-Afrikaanse bodem is. ${ }^{34}$ Dat dit gebeur het, hang enersyds onverbreekbaar saam met die Voortrekkers se beskouing oor die verband en verhouding nasie-staat-owerheid-kerk. Andersyds is dit egter óók te danke aan die Herderlijken Brief van 1837 wat die Voortrekkers afgestoot het en as dwalendes beskou het.

Die Kaapse Kerk, sy vergaderings van die ampte èn sy staatsamptenaarpredikante, het dan ook vir baie jare, uitgaande van die fundamentele sinodale uitspraak in die Herderlijken Brief van 1837 die Voortrekkerkerk met hoofhartige minagting bejeën en die Voortrekkerkerk beskou as 'n kerk waarin daar niks goeds kan wees nie omdat dié kerk nie onder die vlag van imperiale Engeland wou leef nie. Hierdie houding van die Kaapse Kerk in al sy geledinge het 'n kerklike verwydering in die hand gewerk wat tot vandag toe nog voortduur. Die beginpunt van daardie verwydering lê ongetwyfeld in die Herderlijken Brief van 1837 met sy on-Skriftuurlike en ongelooflike dom veroordeling van die Groot Trek.

1. De Handelingen eener buitengewone Synodale Vergadering ens., Kaapstad 1858, bl. 113-114.

2. So is die saak van ds $R$ Shand, wat tydelik geskors was en die kerklike geskille in Kaapstad, uitvoerig behandel. Volgens die Politieke Kommissarisse was die vergadering "disorderly and tumultuous" en word die indruk geskep dat hierdie vergadering nie rustig en na rype oorweging sy besluite geneem het nie. 
Vg. ook E J P Kleynhans, Die Kerkregtelike Ontwikkeling van die Nederduitse Gereformeerde Kerk in Suid-Afrika 1795-1962, Diss US, 1973, bl 56-71.

3. De Handelingen ens, bl 178. Ds van der Lingen was onder die Kaapse predikante beslis ' $n$ uitsondering in dié sin dat hy simpatiek teenoor die Voortrekkers gestaan het. Vgl M C Kitshoff, Gottlieb Wilhelm Antony van der Lingen. Kaapse predikant uit die negentiende eeu, Groningen 1972, bl $62 \mathrm{v} v$ v.

4. A Dreyer, Die Kaapse Kerk en die Groot Trek, Kaapstad 1929, bl 6.

5. Oor die oorsake van die Groot Trek kan en is daar al heelwat gepubliseer. Die werk van C F J Muller, Die Oorsprong van die Groot Trek, Kaapstad-Johannesburg 1974, bl $170 \mathrm{vv}$ is hier gesaghebbend. Hy stel in hierdie verband op bladsy 308: Die Afrikaner, en in die besonder die Afrikaner-grensboer, het reeds gedurende die vorige vyftig jaar algaande meer blyke gegee dat hy besig was om 'n nasionale bewussyn te ontwikkel. Onder die meer resente inwerking van 'n swaar druk van buite, het sy ontluikende samehorigheidsgevoel steeds meer gewas en gedy. Die visie van 'n Afrikanerstaat waarin Afrikanerampsdraers mede-Afrikaners sou help om 'n Afrikanerbeleid in die praktyk uit te lewe, sou die logiese kulminasie van hierdie strewe wees.

6. Dat die ekonomiese argument ook later nie deurslaggewend was nie blyk byvoorbeeld daaruit dat baie Trekkers, na Engeland se anneksasie van Natal, weer die land verlaat het terwyl hulle daar, op die vrugbare bodem, tog 'n goeie bestaan sou kon maak.

7. Vgl die opvatting van Anna Steenkamp, soos aangehaal by C F J Muller, $a w$, bl. 200-201: De schandelijke en onregvaardige handel wijs van de vrijhijt van onser slaven en nogtans heeft de vrijhijt ons so seer niet verdreeven as de geleijkhijt de gelijkstelling met de Christenen, strijdig met de wetten Gods en het natuurlik onderschijt van afkomst en geloof. Dat het onverdraaglijk was voor elk fatsoenlijk Christen onder sulk een last te buijgen waarom wij dan ons liever verwijderen des te beter ons geloof en leer in suyverheijt te behouden.

Die Voortrekkers was nie "rassiste" nie (soos almal vandag beskou word wat die belange en regte van die witman teenoor die nieblanke wil handhaaf) maar dit het vir hulle bowe-al gegaan om die soek na 'n eie vaderland waar hulle self die gemeenskapsorde sou kon bepaal, 'n gemeenskapsorde dus wat in Afrika vir 'n witmansvolk' $n$ definitiewe toekoms sou bied.

$\mathrm{Vgl}$ veral B Spoelstra, Kolonialisme en ons Sendingkrisis gedurende die vorige eeu, artikel in Die Saailand is die Wêreld, Jubileum-uitgawe. Die Hammanskraalse Teologiese Skool, bl 160 en ook bl 184-186.

8. Vgl F A F Wichman, Die Wordingsgeskiedenis van die Zuid-Afrikaansche Republiek 1838-1860, Kaapstad 1941, bl 5.

In Julie 1836 skryf P Retief, soos aangehaal by J L M Franken, Piet Retief se Lewe in die Kolonie, Kaapstad - Pretoria 1949, bl 363-364: Weij gelooft dat weij in Engeland so veragtelik gekend word dat wij nu moed liejden dat de gecouleurde classen nadat se ons van goed en (bloed) berooft hebben, seer reijk beloond word. En weij kan nog sal onse couleur ter veragting van (ons) Maaker en (ter wille van) teijdelij geluk niet verandere ... En wad nogal het ergst, geen tweijvel meer voor ons of seij (dit is die gekleurdes) sullen nog beij alle deese beij het Goevernemind in Engeland waardig geagt worden als oberheersters over ons gesteld te worden. Wad opregt eerlik menslik natuur sal sulks stilsweijgend kunnen leijden?

9. Muller wys daarop dat daar by die Trekkers nog nie ' $n$ duidelike en ontwikkelde nasionale selfbewussyn of nasionalisme was nie maar dat dit aan die ontluik was.

10. Declaratie en Protest van den Volksraad der Emigranten: De Zuid-Afrikaan, 29 November 1839.

Die Engelse koloniale beleid, as hier één begrip gebruik kan word om die oorsake van die Groot Trek saam te vat, was die groot rede. Soos Sir George Clerk in 1853 oor die koloniale beleid geskryf het: ... the neglect and disdain with which it habitually regarded them have engendered a spirit which leaves them with few exceptions by no means desirous of remaining anywhere under British dominion.

11. C F J Muller, $a w$, bl 315. 
12. E J P Kleynhans, $a w$, bl 52.

13 E J P Kleynhans, $a w$, bl 54.

14. Vgl in hierdie verband S P Engelbrecht, Die Geskiedenis van die Nederduitsch Heroormde Kerk van Afrika, Pretoria 1953, bl 29 vv wat daarop wys dat Lord Charles Somerset met hierdie beleid begin het en dat dit daarna voortgesit is. So stel Engelbrecht bladsy 31-32: Nadat hy (dit is Somerset) in 1818 drie Skotte as predikante in die Hollandse kerk aangestel het, het hy in Januarie 1820 na Engeland gegaan; en eers in November 1821 het hy in Suid-Afrika teruggekeer. Hy was vasbeslote om die Afrikaner te verengels, en die wyse van uitvoering het in Engeland die beslag gekry. ' $n$ Paar maande na sy terugkoms, op 5 Julie 1822 , het hy dan ook 'n proklamasie uitgevaardig waarin hy die Hollandse taal as offisiële taak van die kolonie afgeskaf het en Engels as die enigste landstaal verklaar het, ... Vanaf daardie noodlottige jaar 1822 is die skole heeltemal verengels. Hollands is nie meer onderwys nie; voortdurend is daar Skotse predikante vir die Hollandse gemeentes aangestel. Op die Sinode van 1824 was vyf van die dertien predikante Skotte en op die Sinode van 1837 was die helfte van die aanwesige predikante Skotte.

15. Vgl S P Engelbrecht, $a w, b l 33$.

16. B Spoelstra, Die "Doppers" in Suid-Afrika 1760-1899, Kaapstad 1963, bl 101.

17. C F J Muller, Die Britse Owerheid en die Groot Trek, Johannesburg 1963, bl 90 en 97 vv.

18. A Dreyer, $a w$, bl 9 asook S P Engelbrecht, Nogmaals Dr G D Scholtz se Geskiedenis ens, artikel in Hervormde Teologiese Studies, Jrg 13, Pretoria 1958, bl 116-117.

19. B Spoelstra, $a w$, bl. 102.

20. Biografiese gegewens oor ds Herold, 1788-1857, word gegee deur A Dreyer, Eeuwfeest-Album van de Nederduits-Gereformeerde Kerk in Zuid-Afrika 1824-1924, Kaapstad z j. Dit is nogal merkwaardig dat ds Herold wat in 1815 nog die taak gehad het om die Slagtersnek-"martelare" voor en tydens hulle teregstelling by te staan, hoegenaamd niks begryp het van die beweegredes van die grensboere om te trek nie. Hierdie Herderlijken Brief se groot tekortkomings moet dan ook grotendeels aan sy gebrek aan insig van wat in die hart van die Afrikanergrensboer geleef het, toegeskryf word.

21. A Dreyer, Die Kaapse Kerk en die Groot Trek, bl 5 waar 'n koerantverslag uit De Meditator oor dié debat gegee word. Dit is opmerklik dat ds $\mathrm{H}$ A Moorrees téénstem: ... wijl ik de uitgewekene boeren maar nie zoo dadelijk kan veroordeelen" (my kursivering).

22. Vgl in hierdie verband o. a. G P L van der Linde, Die Grondbeginsels van die Presbiteriale Kerkregeringstelsel, Potchefstroom 1965, bl 146 vv waar hy die gesag van die meerdere vergaderings behandel.

23. Die 1824-wet met sy kollegialistiese tendense, oorgeneem uit die 1816 Algemeen Reglement van die Ndle Hervormde Kerk, ken ' $n$ hiërargie van die vergaderings van die ampte.

24. Elis 1858, soos aangehaal by A Breyer, $a w$, bl 27.

25. Vgl S P Engelbrecht, Nogmaals Dr G D Scholtz, bl 116.

26. M C Kitshoff, $a w$, bl 61 .

27. C F J Muller, Die Oorsprong, bl 310.

28. A Dreyer, $a w, b l 5$ waar hy 'n skrywe uit De Zuid-Afrikaan van 'n Colesbergse inwoner aanhaal.

29. B Spoelstra, a $w$, bl. 102.

30. S P Engelbrecht, $a w$, bl. 114-115. So is ds H A Moorrees op 31 Aug 1835 gelegitimeer, eers op 31 Maart 1836 word hy tydelik in Tulbagh aangestel en eers in April 1839 word hy op ' $n$ vaste basis in ' $n$ gemeente aangestel. Ds J J Brink is op 1 September 1835 gelegitimeer en eers in Mei 1839 as predikant aangestel. Dr S P Heyns wat op 21 April 1836 gelegitimeer is, is eers op 21 April $18^{27}$ tydelik aangestel en eers in 1839 op 'n vaste basis. Dr A Roux is in September 1838 gelegitimeer en eers in 1841 as predikant aangestel. Ds P B Borcherds is op 15 Julie 1839 gelegitimeer en eers in $1842 \mathrm{kry}$ hy ' $\mathrm{n}$ tydelike aanstelling. Tereg sê Engelbrecht: Nee, daar was gladnie 'n "akute skaarste aan predikante" nie, maar wel 'n akute skaarste aan simpatie met die Groot Trek.

31. B Spoelstra, a $w$, bl. 103. Sien ook A. Dreyer, $a w$, bl. 10-21. 
32. S P Engelbrecht, Geskiedenis, bl. $45 \mathrm{vg}$.

T N Hanekom, Die Liberale Rigting in Suid-Afrika, Stellenbosch 1951, bl 383 wys daarop dat voornemende Trekkers selfs met die kerklike ban gedreig is.

33. De Zuid-Afrikaan, 5 Junie $1840 . \mathrm{Vg}$ ook A Dreyer, a w, bl. 29.

34. Vgl o a J J Oberholster e a, Die Nederduitse Gereformeerde Kerk in die Oranje Vrystaat, Bloemfontein 1963, bl. $28 \mathrm{vg}$. 